\title{
THE VOWEL SYSTEM OF PODHALE GORALIAN*
}

\author{
JERZY RUBACH \\ University of Iowa, USA, and University of Warsaw, Poland \\ jerzy-rubach@uiowa.edu; jerzy.rubach@uw.edu.pl
}

\section{TOMASZ LUSZCZEK}

University of Warsaw, Poland

t.luszczek@student.uw.edu.pl

\begin{abstract}
This paper is a report on the phonological research done in the past two years investigating Podhale Goralian. The data are drawn from our informants in Dzianisz.

The paper establishes the system of surface contrasts in Goralian and identifies instances of complementary distribution. It is claimed that the renowned Podhale Archaism is no longer represented by the vowel [i]. Rather, the vowel has retracted to the central vowel [i]. The original [i], on the other hand, has lowered and fronted and is now best regarded as tense [e]. These transitions of vowels pose challenges for a phonological analysis. A sample of such analysis (Final Tensing) is shown in the framework of Optimality Theory.
\end{abstract}

Keywords: Optimality Theory, Podhale Goralian, phonology, Polish dialects

\section{Introduction}

This paper is a report on the research done in the past two years investigating Podhale Goralian, a dialect of Polish spoken in the Podhale region of the Tatra Mountains in southern Poland. The data are drawn from our informants in Dzianisz, a village located about $10 \mathrm{~km}$ north-west of Zakopane. We take Dzianisz to be representative of the Podhale region and refer to the dialect as Podhale Goralian. Our fieldwork focused on the generation of speakers who are less than 50 years old. This is important because it may explain why our data differ from those reported in the literature in some significant ways.

The data come from an analysis of recorded interviews that included both free conversation (story telling) and reading of word lists. The recordings were transcribed independently by two professional phoneticians. Much data came

\footnotetext{
We would like to thank the three reviewers of this paper for their comments and suggestions. We have a special debt of gratitude to our native speaker consultants for their help: Anna Łuszczek, Bogusława Łuszczek, Małgorzata Łuszczek, Wojciech Łuszczek, Józef Bąk, Andrzej Kamiński, Stanisław Kamiński, Anna Krupa, Józef Kula, Dorota Pająk, Katarzyna Pająk, Martyna Pająk, Władysław Pająk, Tomasz Płaza, Leszek Stasiwolak, Monika Szwajnos, and Andrzej Zarycki.
} 
directly from one of the authors of this paper, Tomasz Łuszczek, who was born and raised in Dzianisz. He is not only a native speaker of the dialect but also a trained linguist and a phonetician.

Podhale Goralian is the most prominent and best known of the Goralian dialects. There is a huge literature about Podhale culture and language, but all of it is descriptive and not anchored in any theoretical framework. Reports on Podhale Goralian begin with Kopernicki (1875), Kosiński (1884), Kryński (1884), Stopka (1897, 1911), through Nitsch (1915), Małecki (1928) to Kąś (2015). The focus of this research is descriptive and history-driven, addressing, among other things, the question of what properties of Old Polish have been retained in Podhale Goralian.

This paper is a synchronic study. Section 2 introduces the system of vowels and shows basic contrasts. Section 3 looks at the current state of Podhale Archaism. Section 4 presents our proposal of the spelling system for Podhale Goralian. Section 5 is a sample analysis of Final o-Tensing in terms of Optimality Theory. Section 6 concludes the paper with a summary of the most important results.

\section{Vowel System}

The vowels of Podhale Goralian are best illustrated against the background of the Standard Polish vowels. The cardinal vowels diagram in (Figure 1) is cited from Biedrzycki (1974: 28). ${ }^{1}$

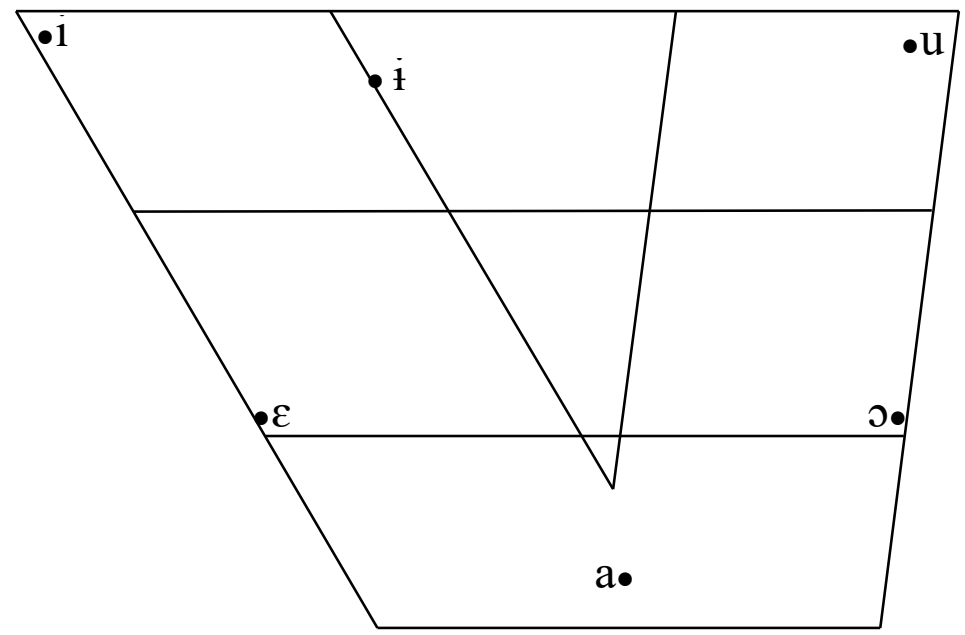

Figure 1. Vowels of Standard Polish

1 We ignore nasal vowels and their decompositions in both Standard Polish and Podhale Goralian. 
The vowels of our speakers from Dzianisz are different in both quantity and quality (for some vowels).

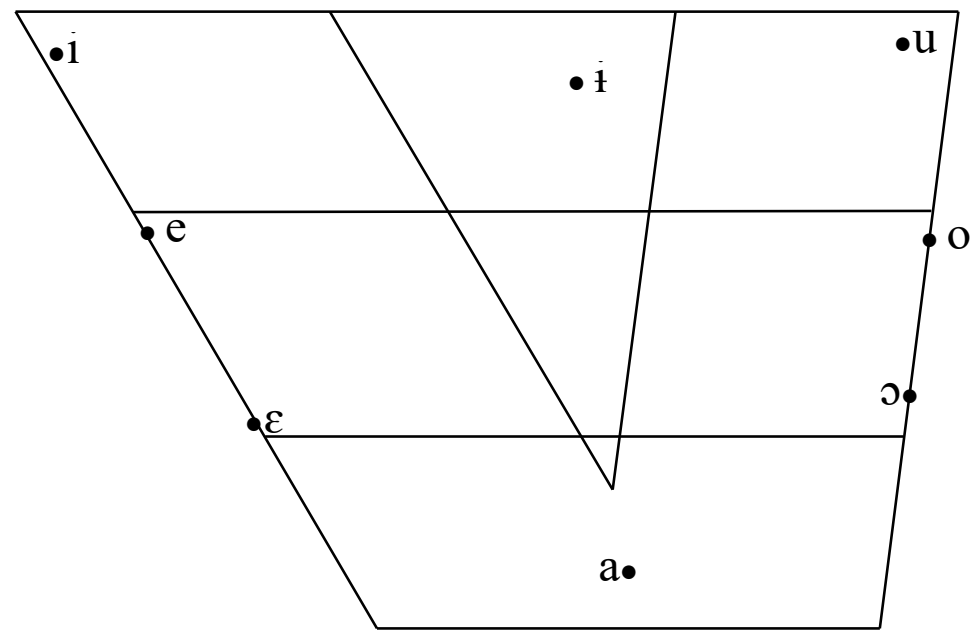

Figure 2. Vowels of Podhale Goralian

High vowels [i] and [u] are identical in (Figure 1) and (Figure 2). The central vowel [i] is different in detail. A comparison of minimal pairs, such as syn [sin] 'son' (Podhale Goralian) and syn [sin] 'son' (Standard Polish), shows that the Podhale Goralian [i] is more retracted than the Standard Polish [i] and sounds like the Russian [i] in syn 'son'.

Podhale Goralian diverges from Standard Polish in that it has four rather than two mid vowels.

$$
\begin{aligned}
& \text { nom.sg. } \\
& \text { chleb [xlep] } \\
& \text { śnieg [cnek] } \\
& \text { próg [prok] } \\
& \text { Bóg [bok] }
\end{aligned}
$$$$
\begin{array}{ll}
\text { gen.sg. } & \text { gloss } \\
\text { chleb+a [xleba] } & \text { 'bread' } \\
\text { śnieg+a [cnєga] } & \text { 'snow' } \\
\text { prog }+\mathrm{a} \text { [proga] } & \text { 'threshold' } \\
\text { Bog+a [boga] } & \text { 'God' }
\end{array}
$$

The additional mid vowels, tense [e] and tense [o], are typical for regional dialects of Polish, for example, they are attested in Kurpian (Rubach 2011). They existed in the standard dialect in Middle Polish, but disappeared in the $19^{\text {th }} \mathrm{c}$.

Tense [e] and [o] have a firm status as contrastive segments. They can be regarded as derivable by rule (Final Syllable Tensing) in the examples cited earlier in (3). This is not true for many other words because tense [e o] do not exhibit alternations. 
(4)

$\begin{array}{lll}\text { nom.sg. } & \text { nom.pl. } & \text { gloss } \\ \text { kołnierz [e] } & \text { kołnierz+e [e] } & \text { 'collar' } \\ \text { lek }[\mathrm{e}] & \text { lek }+\mathrm{i} \quad[\mathrm{e}] & \text { 'drug' } \\ \text { but }[\mathrm{o}]^{3} & \text { but+y [o] } & \text { 'shoe' } \\ \text { król }[\mathrm{o}] & \text { król+e [o] } & \text { 'king' }\end{array}$

Also: apteka [apteka] 'drug store', chlew [xlef] 'pigsty', góra [gora] 'mountain'

In these examples [e o] occur both finally and medially, so they cannot be derived by Final Syllable Tensing. We conclude that //e o// are underlying segments.

The third historically tense vowel is $a$. It occurs in both alternating (5a) and non-alternating $(5 b)$ contexts.

$\begin{array}{rlll}\text { (5) } & \text { gen.sg. } & \text { nom.sg. } & \text { gloss } \\ \text { a. } & \text { przykład }+\mathrm{u} & \text { przykłod } & \text { 'example' } \\ & \text { dziad }+\mathrm{a} & \text { dziod } & \text { 'idler' } \\ & \text { pan }+\mathrm{a} & \text { pon } & \text { 'tourist' } \\ & \text { Jan }+\mathrm{a} & \text { Jon } & \text { 'John' } \\ \text { b. } & \text { ptok }+\mathrm{a} & \text { ptok } & \text { 'bird' } \\ & \text { stow }+\mathrm{u} & \text { stow } & \text { 'pond' } \\ & \text { plebon }+\mathrm{a} & \text { plebon } & \text { 'priest' } \\ & \text { dzbon }+\mathrm{a} & \text { dzbon } & \text { 'pitcher' }\end{array}$

As (5) documents, the Podhale Goralian reflex of the historical tense [a] is $o$. Descriptive sources (for example, Ką́ 2015) characterize this $o$ as an intermediate vowel between [a] and [0]. This characterization is not true for our informants from Dzianisz.
Standard Polish
Podhale Goralian
gloss
a. Polak
Polok [polok]
'Pole'
b. kowal
kowol [kowol]
'blacksmith'

Our informants claim that they perceive the vowels in (6) as exactly the same, and we concur with this judgement. Linguistically speaking, the result is that the neutralization process of the historical [a] with the historical [0] has been completed. As might be expected, the homophony leads to phonological problems because the $[0]$ from $[\mathrm{a}]$ sometimes alternates with [a], as in (5a), and sometimes does not, as in (5b). Addressing this issue is matter of future research.

2 We argue in Section 4 that examples such as this one should be written kothyrz.

3 In Podhale Goralian, the Standard Polish word but 'shoe' is pronounced with [o], not with [u]. Consequently, as we explain in Section 4, it is spelled bót. 
Finally, let us note that the loss of distinction between the two kinds of $o$ shown in Polok (6a) is a recent change. Kąs (2015) asserts that the vowels are different, though likely to be non-distinct with speakers of the younger generation.

To conclude, the vocalic system of Podhale Goralian is richer than that of Standard Polish, but both are rather typical as phonological systems.

\begin{tabular}{cccccc}
\multicolumn{2}{c}{ a. Standard Polish } & \multicolumn{3}{l}{ b. Podhale Goralian } \\
i & $\dot{\mathrm{i}}$ & $\mathrm{u}$ & $\mathrm{i}$ & $\mathrm{i}$ & $\mathrm{u}$ \\
& & & $\mathrm{e}$ & & $\mathrm{o}$ \\
$\varepsilon$ & & 0 & $\varepsilon$ & & 0
\end{tabular}

A featural classification of the system in (7b) poses certain problems. First, with three clearly front vowels [i e $\varepsilon$ ] and three evidently back vowels [u o o], the question is about the status of the two central vowels $[\dot{\mathrm{i}} \mathrm{a}]$ vis-á-vis the feature [ \pm back]. Second, it needs to be determined how to accommodate the additional contrast that obtains in the region of mid vowels.

With regard to the first question, the phonetic facts come to no avail because, technically speaking, [i] and [a] are central. However, the answer is readily provided by the phonological behavior of these vowels.

(8) mróz [mros] 'frost' (nom.sg.)
a. $[\mathrm{mroz}+\mathrm{ik}](\mathrm{dim}):. \mathrm{z} \rightarrow \mathrm{z} / \mathrm{I}_{\mathrm{i}}$
b. $[\mathrm{mroz}+\varepsilon]$ (loc./voc.sg.): $\mathrm{z} \rightarrow \mathrm{z} / \varepsilon^{4}$
c. $[\mathrm{mroz}+\mathrm{i}]$ (nom.pl.), $[\mathrm{mroz}+\mathrm{a}]\left(\bar{g}^{-} \mathrm{en} . \mathrm{sg} .\right)^{5}$

It is common knowledge in phonology that palatalization is caused by front, that is, [-back] vowels. The Goralian data in $(8 \mathrm{a}-\mathrm{b})$ corroborate this claim: the vowels [i] and [ $\varepsilon$ ] trigger the change $z \rightarrow z$, which, in terms of distinctive features, involves a change in the specification of the feature $[ \pm$ back]: [+back] $\rightarrow$ [-back]. In contrast to the forms containing [i] and $[\varepsilon]$ in $(8 \mathrm{a}-\mathrm{b})$, the forms in $(8 \mathrm{c})$ containing [i] and [a] do not cause palatalization: we see $[z]$ rather than $[z]$ in $[\mathrm{mroz}+\mathrm{i}]$ (nom.pl.) and [mroz+a] (gen.sg.). Given this phonological evidence, we conclude that the vowels [i] and [a] must be classified as [+back].

The tense - lax vocalic distinction in the class of mid vowels is readily captured by $[ \pm$ advanced tongue root] ([ $\pm \mathrm{ATR}]$, henceforth). In the class of mid vowels, [+ATR] designates upper mid vowels while [-ATR] refers to lower mid vowels.

Pulling together the observations made about Goralian vowels, we arrive at the following feature chart.

\footnotetext{
${ }^{4}$ This vowel surfaces as tense [e] in fact. It remains unclear whether the change is due to an independently motivated phonological rule or, rather, an allophonic process raising vowels in the vicinity of palatalized consonants.

${ }^{5}$ The gen.sg. ending in Goralian $m r o ́ z$ 'frost' is $-a$, not $-u$.
} 
(9) Podhale Goralian vowels ${ }^{6}$

\begin{tabular}{|c|c|c|c|c|c|c|c|c|}
\hline & $\mathrm{i}$ & $\mathrm{i}$ & $\mathrm{u}$ & $\mathrm{e}$ & $\mathrm{o}$ & $\varepsilon$ & $\jmath$ & $\mathrm{a}$ \\
\hline high & + & + & + & - & - & - & - & - \\
\hline low & - & - & - & - & - & - & - & + \\
\hline back & - & + & + & - & + & - & + & + \\
\hline ATR & + & + & + & + & + & - & - & - \\
\hline round & - & - & + & - & + & - & + & - \\
\hline
\end{tabular}

The vowels in (7b) are all underlying segments because they are contrastive. Some contrasts are obvious, involving many different properties; other contrasts are more subtle, as the following examples demonstrate.

$$
\begin{aligned}
& e-\varepsilon, \quad[\mathrm{lek}] \text { 'drug' - [stek] 'steak' } \\
& \text { [vjes] 'you know' - [vick] 'village'7 } \\
& \text { [poctcel] 'bed' - [tecle] 'calf' } \\
& e-\dot{i}, \quad \text { [sen] 'dream' - [sin] 'son' } \\
& \text { [gzep] 'bury' (imper.) - [gzip] 'mushroom' }
\end{aligned}
$$

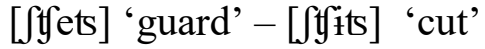

$$
\begin{aligned}
& i-\dot{i}, \quad \text { [noci] 'he carries' - [nosi] 'noses' } \\
& \text { [vozi] 'he transport' - [vozi] 'carts' } \\
& \text { [kozitsa] 'mountain goal' - [zitce] 'life' } \\
& o-u \text {, [bot] 'shoe' - [bus] 'minibus' } \\
& \text { [prok] 'threshold' - [truxwo] 'corpse' } \\
& \text { [dom] 'home' - [duk] 'ghost' } \\
& o-\jmath \quad \text { [mots] 'be able' - [mots] 'power' } \\
& \text { [droga] 'road' - [dron] 'drone' } \\
& \text { [krol] 'king' - [krok] 'step' }
\end{aligned}
$$

The phonological system in (7b) is extended further by diphthongs that originate either from underlying lax //o// or from underlying tense $/ / \mathrm{o} / /$ and derived tense /o/. The diphthongs are optional or rather phonostylistic.

$$
\begin{array}{ll}
\text { o } \rightarrow \text { us } \quad[\mathrm{kot}] \text { or }[\mathrm{kuot}] \text { 'cat' } \\
\\
{[\mathrm{kovol}] \text { or }[\mathrm{kuovsl}] \text { 'blacksmith' }} \\
{[\mathrm{pot}] \text { or }[\mathrm{pust}] \text { 'sweat' }} \\
{[\mathrm{po}] \text { or }[\mathrm{pu}] \text { 'after' }}
\end{array}
$$

\footnotetext{
${ }^{6}$ Goralian contrasts lax and tense vowels only in the mid region, thus the vowels [i i $\mathrm{u}$ a] are specified for $[ \pm \mathrm{ATR}]$ in a redundant manner.

${ }^{7}$ The $[\varepsilon]$ is raised by an allophonic or phonetic implementation process operating in the context of palatalized consonants, but the raising is not significant enough to obliterate the contrast with tense [e].
} 


$\begin{array}{ll} & \text { [botsitc] or [bustsite] 'hold a grudge' } \\ & \text { [nove] or [nuəve] 'new' } \\ & \text { [gora] or [guora] 'mountain' } \\ & \text { [mleko] or [mlekuo] 'milk' } \\ & \text { [kon] or [kuon] 'horse' } \\ & \text { [vor] or [vuor] 'sack' (augment.) } \\ & \text { [bo] or [buo] 'why' } \\ & \text { [dom] or [duom] 'home' }\end{array}$

The point of interest is that the diphthongs have the status of short rather than long vowels, which is natural as Podhale Goralian is not a weight-sensitive dialect. The $[\mathrm{u}]$ onglide of the diphthong is subsegmental because native speakers perceive a difference between [wo] and [u॰] as well as between [wo] and [uo]. ${ }^{8}$

a. plot [pwot] 'fence' is not the same as pot [pust] 'sweat'

$k$ tos [kwos] 'ear of corn' is not the same as kos [kuos] 'blackbird'

$k$ tadt [kwot] 'he laid' is not the same as kot [kuot] 'cat

b. chtód [xwot] 'cold' is not the same as chód [xuot] 'gait'

tto [two] 'background' is not the same as to [tuo] 'this'

kłonica [kwonitsa] 'rod' is not the same as konnica [kuonnitsa] 'cavalry'

The [uo] and [uo] strings are diphthongs, not sequences of [u] and [0] or [o] because the words in (12) are perceived by native speakers as monosyllabic. ${ }^{9}$ Thus, [pust] 'sweat' (nom.sg.) is one syllable, not two, while [pust+u] (gen.sg.) is two syllables, not three syllables.

We conclude that Podhale Goralian has short diphthongs. Technically, they are represented as two root nodes linked to a single mora or X-slot, depending on the skeletal theory. Rt stands for the Root node. ${ }^{10}$

a. moraic theory

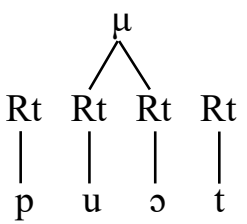

b. X-skeletal theory

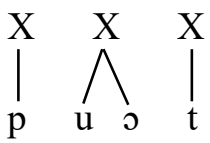

The occurrence of short diphthongs is interesting typologically because short diphthongs are extremely rare. The only well-known case is Spanish, for which

\footnotetext{
${ }^{8}$ This is based on the judgements made by native speakers, who were asked whether pairs such as plot 'fence' and pot 'sweat' in (12a) sounded the same or different. The judgement was that they were different. The same conclusion was reached independently by the transcribers.

${ }^{9}$ [kwojitsa] and [kuonnitsa] have three syllables each.

${ }^{10}$ We assume the Halle-Sagey feature geometry (Halle 1992, Sagey 1986).
} 
they have been reported by Clements and Keyser (1983). While the occurrence of short diphthongs in Podhale Goralian is a firm fact, ${ }^{11}$ the circumstances under which they are actually used are not entirely clear. The general observation is that diphthongs are used for emphasis in an obligatory way. Other stylistic use of diphthongs is not clear and requires research.

\section{Podhale Archaism}

Goralian is renowned in Polish linguistic literature for the so-called Podhale Archaism (archaizm podhalański). The matter has drawn the attention of linguists ever since the first studies of Podhale Goralian in the $19^{\text {th }}$ c., from Kosiński (1884), Nitsch (1915), Małecki (1928) to Dejna (1973) and Decaux (1973).

Historical grammarians, for example, Rozwadowski (1915), Stieber (1952, 1973) are in agreement that until the 16th c., Polish stridents were soft, that is [-back], segments: [ts $\left.\mathrm{t}^{\mathrm{j}} \mathrm{tg}^{\mathrm{j}} \mathrm{d} \mathrm{g}^{\mathrm{j}} \int^{\mathrm{j}} \mathrm{z}^{\mathrm{j}}\right]^{12}{ }^{12}$ Consequently, they combined with the front vowel [i] rather than with the back vowel $[\mathrm{i}],{ }^{13}$ as the following examples show.

\begin{tabular}{|c|c|c|c|}
\hline chtopcy & $\begin{array}{l}\text { 15th c. Polish } \\
\text { [xłoptsii] }\end{array}$ & $\begin{array}{l}\text { modern Polish } \\
\text { [xwoptsi] }\end{array}$ & $\begin{array}{l}\text { gloss } \\
\text { 'boys' }\end{array}$ \\
\hline drodzy & [drodzii] & [drodzi] & 'dear' (nom.pl.) \\
\hline$c z y$ & {$\left[\mathrm{~g}^{\mathrm{ji}} \mathrm{i}\right]$} & {$[\mathrm{tg} \mathrm{i}]$} & 'if' \\
\hline$s z y c ́$ & [Sitc] & [Sit6] & 'sew' \\
\hline zyto & [3 $\left.3^{\mathrm{jit}}\right]$ & [3ito] & 'rye' \\
\hline
\end{tabular}

The original soft [ $\left[\mathrm{s}^{\mathrm{j}} \mathrm{k}^{\mathrm{t}} \mathrm{g}^{\mathrm{j}} \mathrm{d} \mathrm{z}^{\mathrm{j}} \int^{\mathrm{j}} \mathrm{3}^{\mathrm{j}}\right.$ ] hardened, that is, became [+back], in the 16th $\mathrm{c}$. The fallout of Hardening is different in different Slavic languages and dialects. For example, Ukrainian has retained soft [tsi] (Bilodid 1969) while Russian has kept soft [t'] (Avanesov 1968). Lower Sorbian is still different: it has retained soft

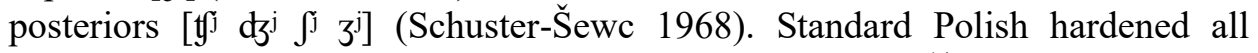
stridents, the consequence being that [i] was replaced by $[\mathrm{i}] .^{14}$

(15) Hardening ts $\mathrm{d}^{\mathrm{j}} \mathrm{tg}^{\mathrm{j}} \mathrm{d} \mathrm{z}^{\mathrm{j}} \int^{\mathrm{j}} \mathrm{z}^{\mathrm{j}} \rightarrow$ ts d $\mathrm{t} d \mathrm{~d} \int 3^{15}$

Hardening did not affect Podhale Goralian, so examples such as those in (12) have retained their original [i]. It is this fact that is called Podhale Archaism (archaizm

\footnotetext{
11 The literature talks about 'labialized $o$ ' that can occur word-medially; see, for example, Kąś (2015).

${ }^{12}\left[\mathrm{~d}^{\mathrm{j}}\right]$ spirantized to [3 $\mathrm{3}^{\mathrm{j}}$.

${ }^{13}$ Central vowels are characterized as [+back] in generative phonology.

${ }^{14}$ For discussion, see Rubach $(2003,2017)$.

${ }^{15}$ The generalizations in this section are descriptive. A sample of a formal analysis is provided in Section 5.
} 
podhalański): the retention of [i] is archaic because it reflects the state of Polish in the $15^{\text {th }} \mathrm{c}$. The actual pronunciation of the examples in (12) diverges from the $15^{\text {th }} \mathrm{c}$. pronunciation in one way: Podhale Goralian, like many other regional dialects of Polish (for example, Kurpian), has developed a rule that we will call Dentalization (mazurzenie).

(16) Dentalization (mazurzenie) $\operatorname{t} d \mathrm{~d} \int 3 \rightarrow$ ts $\mathrm{d} \mathrm{s} \mathrm{z}^{16}$ context-freely

The combined effect of Dentalization and the retention of archaic [i] yields the following pronunciation of the examples in (14).

(17) Podhale Goralian Archaism

a. Archaism:

chłopcy [xwoptsii] 'boys'

drodzy [drockii] 'dear' (nom.pl.)

b. Archaism plus Dentalization:

czy [tsii] 'if'

szyć [siitc] 'sew'

żyto [ziito] 'rye'17

Małecki (1928) notes that the [i] of Podhale Archaism is not the same as the [i] in other contexts, such as in pic 'drink'. He claims that it is an intermediate vowel between [i] and [i], so probably [I], which he proposes to represent in the spelling with a new letter: $y$. Małecki (1928) makes two other important points. First, he notes that the territory on which Podhale Archaism operates starts shrinking. Second, the villages that exhibit the Archaism, Dzianisz including, exhibit it in a robust way: the Archaism is very much alive and productive.

Our fieldwork carried out in Dzianisz almost a hundred years later shows that Podhale Goralian has undergone a dramatic change since the time when Małecki collected his data: the [i] or [I] has completely disappeared in the language of Goralians who are 50 years old or younger. What we find is [i] in the very same Podhale Archaism words.

(18) Change of Podhale Archaism in Dzianisz

$$
\text { chłopcy 'boys' } \quad \text { [xw॰ptsii] } \rightarrow \text { [xwっptsi }]
$$

\footnotetext{
${ }^{16}$ Less frequently, $t \mathrm{~d}$ d $\int 3 \rightarrow$ to do $6 \mathrm{z}$.

${ }^{17}$ It is probably Dentalization that is responsible for the extension of the Archaism to words with the original $[\mathrm{s} \mathrm{z}]$ because the original $[\mathrm{s} \mathrm{z}]$ and the $[\mathrm{s} \mathrm{z}]$ from Dentalization are non-distinct. The consequence is that Podhale Archaism now encompasses also words such as syn 'son' and zysk 'profit'.
} 


$\begin{array}{ll}\text { drodzy 'dear' (nom.pl.) } & \text { [drodjii }] \rightarrow \text { [drodzi }] \\ \text { czy 'if } & {[\text { tsii } \rightarrow[\text { tsi }]} \\ \text { szyć 'sew' } & {[\text { sitt }] \rightarrow[\text { sitc }]} \\ \text { żyto 'rye' } & {[\text { ziito }] \rightarrow[\text { zito }]^{18}}\end{array}$

The 'new [i]' in (18), shown earlier in diagram (1b), is definitely not a front but a central vowel and sounds much like Russian [i]. The 'new [i]', exactly like the original Podhale Archaism, extends to the context of historical [s z], such as in syn [sin] 'son' and zysk [zisk] 'profit'.

The rise of 'new [i]' leads to the question of what has happened to the 'old [i]' in contexts other than those defined by Podhale Archaism. The answer is that the 'old [i]' has totally disappeared because it has collapsed with tense [e].

(19) Vowel Transition [i] $\rightarrow$ [e]

Since Vowel Transition did not occur in the Podhale Archaism contexts, it can be surmised that Podhale Archaism blocked or undid the effects of Vowel Transition. A theoretical analysis of this issue awaits future research.

As already noted, Podhale Goralian has tense [e] in words inherited with tense [e] from Old Polish, such as chlew [xlef] 'pigsty', grzech [gzex] 'sin' and sierp [cerp] 'sickle'. The point of interest is that native speakers judge the following words as containing the same vowel in both syllables. Consequently, the transcription must be as given below.

$$
\begin{aligned}
& \text { chlew+y [xleve] 'pigsties' } \\
& \text { grzech+y [gzexe] 'sins' } \\
& \text { sierp+y [cerpe] 'sickles' }
\end{aligned}
$$

At the same time the vowels in the following words are judged as different, a fact that we note in the transcription.

$$
\begin{aligned}
& \text { syty [site] 'full' } \\
& \text { syny [sine] 'sons' } \\
& \text { czysty [tsiste] 'clean' }
\end{aligned}
$$

The facts in (21) fit into our story: after the Podhale Archaism consonants, here [s ts], we have [i] while [e] for 'old [i]' occurs elsewhere.

We wish to make a further observation. The speakers in Dzianisz have extended the classic Podhale Archaism context not only to the original [s z], exemplified by syn [sin] 'son' and zysk [zisk] 'call', but also to the posterior fricatives [ [] and [3] that are the effects of $r$-Palatalization.

\footnotetext{
${ }^{18}$ The actual surface form is [zito], with the word-final //o// changed to [o]. See Section 5.
} 
(22)
trzy 'three': [ $\mathrm{t} \hat{\jmath}]$, not $*\left[\mathrm{t} \int e\right]$ or $*\left[\mathrm{t}^{j} i\right]$
krzywy 'crooked' [kfive], not *[kSeve] or *[kjive]
Rzym 'Rome' [3im], not *[3em] or *[3 $3^{\mathrm{jim}]}$
przyroda 'nature' [p $\left.\int \dot{\text { troda}}\right]$, not *[p $\int e$ eroda $]$ or *[p $\int^{\dagger} i$ roda $]$

In sum, the descriptive generalization is that 'new [i]' occurs in the following contexts.

(23) Distribution of 'new [i]'

The vowel [i] occurs after hard stridents [s z ts dz $\left.\int 3\right]$, regardless of whether the source is Dentalization, $r$-Palatalization or the underlying representation.

To conclude, somewhat paradoxically, the dramatic sound change $i \rightarrow i$ has not eliminated Podhale Archaism, but made it different: the hallmark of Podhale Archaism is now the occurrence of [i], not of [i]. The transition of 'old [i]' to [e] poses huge challenges for phonological theory. For one thing, we have a front vowel (tense [e]) that does not cause Palatalization. These challenges constitute a research agenda for the future.

\section{Spelling}

We have now identified the relevant vowel types of Podhale Goralian. This leads to an important practical question: how should these distinctions be noted in the spelling?

There has been much debate about the spelling of Podhale Goralian. Stopka (1897) uses accented $y$ to spell the vowel of Podhale Archaism. ${ }^{19}$ In a later publication (Stopka 1911), he rejects $y$ in favour of $\bar{t}$.

(24) Spelling of Podhale Archaism

$\begin{array}{llll}\text { Standard Polish } & \text { Stopka (1897) } & \text { Stopka (1911) } & \text { gloss } \\ \text { czysty } & \text { cýsty } & \text { cīsty } & \text { 'clean' } \\ \text { szyć } & \text { sýć } & \text { síć } & \text { 'sew' } \\ \text { żyć } & \text { zýć } & \text { zíć } & \text { 'live' } \\ \text { syn } & \text { sýn } & \text { sīn } & \text { 'son' } \\ \text { zysk } & \text { zýsk } & \text { zīsk } & \text { 'profit' }\end{array}$

\footnotetext{
${ }^{19}$ Kopernicki (1875) also uses $y$ in the same context to represent, as he puts it, long $y$.
} 
Years later in his monograph, Małecki (1928) returns to $y$, but assigns it a new quality: $y$ denotes an intermediate vowel between $i$ and $y$. The letter $y$ is used still today and denotes an [i] type vowel (Kąś 2015), not an [i] vowel. Given this tradition, we cannot retain $y$ to mean the Podhale Archaism vowel because we have determined that the vowel is [i], not a front vowel of an [i] type. Our proposal is to introduce the letter $\bar{y}$ to represent the central vowel [i].

We go along with the widely spread tradition of writing $y$ to mean tense [e] for the historical chléb [xlep] 'bread' and chlyw [xlef] 'sty', as in Dejna (1973). However, as explained in Section 3, we take all $y$ 's to stand for [e], not only those $y$ 's that correspond to the historical tense é. Dejna (1973) has a different view. He transcribes brzég 'shore', rzéka 'river' and śniég 'snow' as [bžyk], [žyka] and [śńyk], respectively, and claims that tense [e] has narrowed to [y]. ${ }^{20}$ This is the opposite of what we are saying. In our view, it is the [y] (our 'old [i]) that has lowered to tense [e].

Consequently, we have the following spelling of Standard Polish words in Podhale Goralian. The words in (25) exemplify [e] and the Podhale Archaism [i] discussed earlier.

$\begin{array}{cl}\text { 5) } & \text { Standard Polis } \\ \text { a. } & \text { grzech [gzex] } \\ & \text { jeż [jef] } \\ & \text { zlew [zlef] } \\ \text { b. } & \text { czysty [tfisti] } \\ & \text { szyć [jitc] } \\ & \text { żyć [3itc] } \\ & \text { syn [sin] } \\ & \text { zysk [zisk] }\end{array}$

Podhale Goralian
grzych [gzex]
jyż [jef]
zlyw [zlef]
cȳsty [tsiste]
sȳć [sitt]
zȳć [zitc]
sȳn [sin]
zȳsk [zisk]

gloss
'sin'
'hedgehog'
'sink'
'clean'
'sew'
'live'
'son'
'profit'

We agree with the established tradition across Polish regional dialects that tense [o] is simply written as $o$. The representation of the diphthongs is a little problematic. It is common practice to use the letter $\hat{o}$ to represent both [u०] as in kot [kust] 'cat', written kôt, and word-initial epenthetic [w], as in owca [woftsa] 'sheep', written ôwca. The spelling of both postconsonantal [uo] and the onset- $o$ sequence [wo] in the same way as $\hat{o}$ is a problem because we believe that they are different phonological beings: [uv] is a short diphthong while [wo] is an epenthetic effect of the constraint ONSET that penalizes onsetless syllables. The distinction is not only theory-driven. As shown in Section 3, native speakers perceive [uv] and [wo] as different, so they need to be spelled differently. Our suggestion is to use $\check{o}$ (hacek $o$ ) for the lax diphthong [u०] and $t$ for epenthetic [w]. ${ }^{21}$ The tense

\footnotetext{
${ }^{20}[\mathrm{y}]$ is the Slavic way of representing IPA [i]].

${ }^{21}$ We have decided against using $\hat{o}$ because of the confusing content that authors assign to it. In addition to [u॰] and [wo] just discussed, it has been suggested that $\hat{o}$ should stand for plain [0] (Kąś 2012).
} 
diphthong [uo] derived from tense [o], as in [guora] 'mountain', has never been discussed in the literature before, so the spelling has never been suggested either. We propose to use the letter $\ddot{o}$ for [uo], so [guora] is written göra.

The table in (26) summarizes the orthoepic relations between vowel letters and vowel sounds.

(26) Vowel letter - sound correspondences in Podhale Goralian

\begin{tabular}{|c|c|c|c|}
\hline Letter & IPA Symbol & Description & Example \\
\hline $\bar{y}$ & {$[\mathrm{i}]$} & unrounded central vowel & sȳć [sitt] 'sew' \\
\hline $\mathrm{y}$ & {$[\mathrm{e}]$} & mid tense unrounded front vowel & chlywy [xleve] 'pigsties' \\
\hline ó & {$[\mathrm{o}]$} & Mid tense rounded back vowel & król [krol] 'king' \\
\hline ǒ & {$[\mathrm{u}]$} & short lax diphthong & kǒt [kuot] 'cat' \\
\hline ö & {$[\mathrm{uo}]$} & short tense diphthong & göra [guora] 'mountain' \\
\hline
\end{tabular}

The other vowel letters, $i, u, e, o$, and $a$, represent the same sounds as in Standard Polish: [i u $\varepsilon$ o] and [a], respectively.

In addition to defining the representation of vowels, we propose to simplify the representation of prepalatals [ $6 \mathrm{z}$ t6 $\mathrm{d} / \mathrm{n}$ ]. To see the point, we need to first consider the spelling system for prepalatals in Standard Polish. Every prepalatal is spelled in three different ways.

(27) Standard Polish

a. Before a consonant or a word boundary, prepalatals are spelled with an accent over the letter.

[6]: kość 'bone', struś 'ostrich'

[ъ]: groźba 'threat', paź 'page'22

[t6]: ć́wiczenie 'exercise', kapeć 'slipper'

[њ]]: dźwig 'crane', sledź 'herring'

[n]: kończyć 'end', leń 'lazy person'

b. Softness is marked not by an accent but by the letter $i$ if $i$ is followed by another vowel letter; in that case, $i$ functions as a diacritic and is not pronounced, unless the preceding consonant is a labial. ${ }^{23}$

[6]: $\quad$ siano [6ano] 'hay'

[z]: ziarno [zarno] 'grain'

[t6]: ciasto [tcasto] 'cake'

[њ]: działo [dzawo] 'cannon'

[n]: nie [ne] 'no'

22 Polish has Final Devoicing, so paź and śledź (below) are pronounced with a voiceless obstruent.

${ }^{23}$ A reviewer asks about the context of velars, as in kiedy 'when', giez 'hadfly' and hiena 'hyena'.

The answer is that $i$ is pronounced as [j] after velar fricatives, but not after velar stops: [kjedi], [gjes], [xjjena]. 
Labials: piasek [pjjasek] 'sand', biały [bjjawi] 'white', miasto [mijasto] 'town', wiadro [vjjadro] 'bucket, parafia [parafjja] 'parish'

c. Prepalatals are written as plain consonants before $i$ that is not followed by a vowel; so the $i$ has two functions: (i) it is a nucleus and (ii) it is a diacritic denoting softness.

$$
\begin{aligned}
& \text { siwy [civi] 'gray' } \\
& \text { zimny [zimni] 'cold' } \\
& \text { cichy [tcixi] 'quiet' } \\
& \text { dziki [dikiij] 'wild' } \\
& \text { nic [nits] 'nothing' }
\end{aligned}
$$

As noted, this is a complex system, with three ways of spelling the same sound. Particularly disturbing is the situation when the same sound in the same morpheme is spelled in two or even three ways.

(28) struś 'ostrich' (nom.sg.): [6] spelled with an accent as ś, [struc] strus+ia (gen.sg. $)^{24}$ : [6] spelled with mute $i$, [struca]

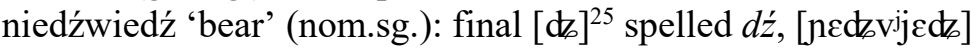
niedźwiedz+ia (gen.sg.): the same [ł] spelled with mute $i$, [nedzvjjecka] niedźwiedz $+\mathrm{ic}+\mathrm{a}$ 'she bear': here [Њ;] is spelled $d z i$, where $i$ is pronounced, [ned̋vjjedzitsa]

The paradox is that this complex system turns out to be not complex enough in order to represent different sounds in an adequate way. For example, the si in sinus 'sine', the $z i$ in Zanzibar 'Zanzibar' and the $c i$ in na cito 'urgently' falsely suggest that the pronunciation is *[6i], *[zi] and *[tci], respectively. The attested pronunciations are $\left[\mathrm{s}^{\mathrm{ji}}\right]$, [ $\left.\mathrm{zi}^{\mathrm{i}}\right]$ and [ $\left.\mathrm{t} \mathrm{ij}\right]$.

All of these complexities and inadequacies are avoided if we adopt the following spelling convention.

(29) Spelling of prepalatals

The only way to spell [ $6 \mathrm{z}$ to $\mathrm{d} / \mathrm{n}$ ] is by using an accent, so by using the letters $\dot{s}, \dot{z}, \dot{c}, d \dot{z}$, and $\dot{n}$, respectively.

Given this principle, the Standard Polish examples in $(27 \mathrm{~b}, \mathrm{c})$ and in (28) would be spelled as follows.

\footnotetext{
24 The masculine forms strus $+i$ and niedźwiedz+ $i$ (below) belong to the category illustrated by niedźwied $z+i c+a$ 'she bear' below, where $i$ appears in two functions: it is pronounced and denotes palatalization

${ }^{25}$ We ignore Final Devoicing.
} 
(30)

\begin{tabular}{|c|c|}
\hline śanó [cano] 'hay' & śiwy [cive] 'gray' \\
\hline źarnó [zarno] 'grain' & źimny [zimne] 'cold' \\
\hline ćastó [tcasto] 'cake' & ćichy [tcixe] 'quiet' \\
\hline dźałó [đławo] 'cannon' & dźiki [dzikii] 'wild' \\
\hline ńy [ne] 'no' & ńic [nits] 'nothing' \\
\hline struś 'ostrich' (nom.sg.) & struś $+\mathrm{a}$ [struca] (gen.sg.) \\
\hline & wiydź+a [nєdzvijectza] ( \\
\hline
\end{tabular}

The troublesome examples, sinus 'sine', Zanzibar 'Zanzibar' and na cito 'urgently' are not a problem any longer: they are not pronounced with *[6i], *[zi] and *[tci] because they are not written *'ínus, *Zanźibar and *na ćito. To conclude, we adopt the principle in (29), so the only correct way of spelling prepalatals in Podhale Goralian is to use accented letters, as shown in (30).

The principle adopted here that spelling should reflect the facts of pronunciation as closely as possible ${ }^{26}$ has a consequence for writing glides. The rule is simple: glides are written where they are heard. The glide [w] is written $t$ and the glide [i] is spelled $j$, as the following examples illustrate.

(31) Spelling of glides

a. łosa [wəsa] 'wasp'

łokó [woko] 'eye'

łowca [woftsa] 'sheep'

łokap [wokap] 'cooker hood'

łozwa [wozva] 'echo'

pałza [pawza] 'pause'

Ełrópa [عwropa] 'Europe' b. pjosek [pjjosck] 'sand' bjoły [bjjowe] 'white' mjastó [mjjasto] 'city' fjołek [fjowek] 'violet' wjeś [ $\mathrm{v}^{\mathrm{j} j \varepsilon s ́}$ ' 'village' Ałstralja [awstral jija] 'Australia' intujicja [intujitsja] 'intuition'

The glide $[\mathrm{w}]$ can be written $t$ with impunity today because the classic pronunciation of $l$ as dark $l[1]$ hardly exists: it can be found only with the oldest speakers (in their 80's and 90's).

The final question concerns the correspondences in the spelling and pronunciation between the vowels of Standard Polish and the vowels of Podhale Goralian. The correspondences are represented as follows.

(32) Vowel correspondences: Standard Polish - Podhale Goralian

a.

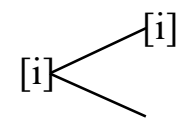

${ }^{26}$ Spelling should not be confused with transcription. There are certain details of pronunciation that need not, or even should not, be reflected in the spelling because then the spelling is not practical. 
[e]

Standard Polish

nosić

szuścić

b.<smiles>C1[AlH][AlH2]1</smiles>

Standard Polish

grzyb

tyle

wyrywać

c.<smiles>[AlH2][Hg]</smiles>

Standard Polish pukać

dziura

d.<smiles>ClC(Cl)(Cl)Cl</smiles>

Standard Polish

zero

chlew

tyle

siekiera

e.<smiles>[AlH2][AlH2]</smiles>

Standard Polish młot

$\begin{array}{ll}\text { Podhale Goralian } & \text { gloss } \\ \text { noś[i]ć } & \text { 'carry' } \\ \text { suść[e]ć } & \text { 'rustle' }\end{array}$

Podhale Goralian gloss

$\operatorname{grz}[\mathrm{i}] \mathrm{b}$

$\mathrm{t}[\varepsilon]$ ló

wyr[u]wać

'mushroom'

'this much'

'pluck out'

Podhale Goralian gloss

$\mathrm{p}[\mathrm{u}] \mathrm{kać}$

dź[o]ra

'knock'

'hole' $\begin{array}{ll}\text { Podhale Goralian } & \text { gloss } \\ \mathrm{z}[\varepsilon] \mathrm{ró} & \text { 'zero' } \\ \text { chl[e]w } & \text { 'sty' } \\ \text { tel[o] } & \text { 'this much' } \\ \text { ś[i]kjyra } & \text { 'axe' }\end{array}$
Podhale Goralian gloss

$\mathrm{m}$ [0]t 'hammer' 


$\begin{array}{lll}\text { wiadro } & \text { wjadr[o] } & \text { 'bucket' } \\ \text { komora } & \mathrm{k}[\mathrm{u}] \text { móra } & \text { 'chamber' } \\ \text { miotła } & \mathrm{mj}[\varepsilon] \mathrm{tla} & \text { 'broom' }\end{array}$

f. $\quad[\mathrm{a}\} \begin{array}{r}{[\mathrm{a}]} \\ {[\mathrm{o}]}\end{array}$

$\begin{array}{lll}\text { Standard Polish } & \text { PodhaleGoralian } & \text { gloss } \\ \operatorname{mama} & \mathrm{m}[\mathrm{a}] \mathrm{m}[\mathrm{a}] & \text { 'mother' } \\ \text { szpak } & \mathrm{s} p[\mathrm{o}] \mathrm{k} & \text { 'starling' } \\ \text { trafić } & \operatorname{tr}[\varepsilon] \mathrm{fić} & \text { 'hit the mark' }\end{array}$

\section{Sample analysis}

As already noted, working out the phonological system of Podhale Goralian is a huge and complex project. We exemplify the issue by looking at a single problem that appears to be straightforward: Final $o$-Tensing. The data come $100 \%$ from our fieldwork; the generalizations that emerge from the data are new and have never been reported in the literature.

(33) Final tense $[0]$

neuter nom.sg.: lat $+o ́$ [o] 'summer', błot+ó [o] 'mud', lustr $+o ́$ [o] 'mirror'27

fem. voc. sg.: bab+ó [o] 'woman', idjotk $+o^{28}$ [o] 'idiot', mam+ó [o] 'mother'

adverb. suffix: hrub+ó [o] 'thick' (Adv.), thust $+o ́$ [o]'fat' (Adv.), mał+ó [o] 'little'

Adj. masc. gen.sg.: hrub+egó [o] 'thick' (Adv.), thust+egó [o]'fat' (Adv.), mał+egó [o] 'small' (Adv.)

Also: bó [o] 'because', hó [o] (exclamation word used with horses)

It appears that what we are looking at is a rule of Final o-Tensing. Schematically:

(34) Final $\lrcorner$-Tensing: $\quad 0 \rightarrow 0 /-\#$

\footnotetext{
${ }^{27}$ Since generative phonology reasons in term of morphemes rather than words, these three nouns represent one example: the nom.sg. ending.

${ }^{28}$ The spelling with $j$ rather than with $i$ follows from the phonetic principle introduced in the preceding section that glides are written where they are heard.
} 
Final $\jmath$-Tensing is challenged by the following examples:

(35) Final lax [0]

verbalizing suffix: $\quad c \bar{y} t+o[0]$ 'he reads', śpjyw $+o[0]$ 'he sings', gr+o [0] 'he plays'

Adj. fem. nom.sg.: $\quad$ hrub $+o$ [o] 'fat', thust $+o$ [0] 'fat', wysók $+o$ [0] 'tall'

fem. nom.sg.:

plebańj $+o^{29}[0]$ 'presbytery', litańj $+o$ [o] 'litany', łoperacj $+o[0]$ 'surgery'

Also: jo [0] 'I', co [0] 'what', wjo [0] (exclamation word used with horses), mo [0] 'he has', sto [0] 'hundred', ło [0] 'about', po [0] 'after', zoo [0] 'zoo', dlo [0] 'for', do [0] 'to', no [0] 'yes', pstro [0] 'nothing', śo [0] 'go away' fto [o] 'who'

A comparison of the data in (33) and (35) raises the fundamental question of whether there is any generalization to speak of. Six examples in (33) show final tense [o] and seventeen examples in (35) show final lax [0]. There is a contradiction.

How do we know that the opposite of Final $\supset$-Tensing is not true, that is, why can't we assume that final $o$ 's in (35) are tense in the underlying representation and they become lax through the action of Final $o$-Laxing. Schematically:

(36) Final $o$-Laxing: $\quad 0 \rightarrow 0 /-$ \#

The numbers alone, seventeen with final lax [0] in (35) versus six with tense [o] in (33), give preference to Final $o$-Laxing over Final $\supset$-Tensing. However, there are two reasons showing that Final $\supset$-Tensing is a better analysis than Final $o$-Laxing: first, phonological plausibility and, second, the treatment of borrowings and foreign names.

Final $\lrcorner$-Tensing is a natural process supported, for example, by English. In The Sound Pattern of English (1968), Chomsky and Halle argue that words such as motto [marov] and veto [vi:rov] should derive their final diphthong by Final $\supset$ Tensing, $\supset \rightarrow o$, and Diphthongization, $o \rightarrow o v$. The argument is that motto could not have tense $/ / \mathrm{o} / /$ and hence //ov// in the underlying representation because heavy syllables (here: syllables with a long vowel or a diphthong) attract stress: ${ }^{30}$ SPE rules assign stress to the second syllable of balloon, serene, suppose, retain, and so forth. To conclude, motto derives from underlying //mato//. The //o// tenses

\footnotetext{
29 This suffix is dying out in the form of [0]. Our teenage consultants as well as those in their 30s and 40 s confirm that the youngest generations of Goralians invariably realise the fem. nom.sg suffix as [a].

${ }^{30}$ The technical details are different, but they are not relevant. SPE used tenseness rather than length to define heavy syllables; see Chomsky and Halle (1968).
} 
to [o] by Final Tensing and diphthongizes to [ov] by Diphthongization. Flapping completes the derivation, yielding the surface [marov]. We conclude that Final $っ$ Tensing as a process is supported independently by stress facts of English.

The second argument for postulating Final $\supset$-Tensing rather than Final $o$ Laxing comes from the behaviour of borrowings and foreign names.

$$
\begin{array}{ll}
\text { Marcó Poló [marko polo] } & \text { Galileó [galijleo] } \\
\text { Paló Altó [palo alto] } & \text { Toledó [toledo] } \\
\text { Tokió [tokijo] } & \text { Chicagó [jikago] } \\
\text { discó poló [dijsko polo] } & \text { judó [ḑ̧udo] }
\end{array}
$$

The final $o$ is invariably tense in (37). The tensing must be due to a rule because the input has a lax [0], as can be gleaned from the fact that lax $o$ appears in the first syllable of Poló [polo]. Borrowings and foreign names, unlike the morphemes in (33) and (35), constitute an open class, so it is not possible to assume that [o] comes from the underlying representation. We conclude that Final $\supset$-Tensing is the correct descriptive generalization about Podhale Goralian.

The informal statement of Final $っ$-Tensing in (34) raises the question of how this generalization and the process it represents can be analyzed in terms of Optimality Theory (Prince and Smolensky 2004, McCarthy and Prince 1995). First, the rule needs to be restated as a constraint and, second, we need to identify faithfulness violations incurred by the tensing operation $\supset \rightarrow o$.

(38) Final $っ$-Tensing, * ’\#

No final lax [o].

In terms of distinctive features, the tensing $\supset \rightarrow o$ changes [-ATR] to [+ATR], which violates IDENT[ \pm ATR].

(39) IDENT[ $[ \pm \mathrm{ATR}]$ : The value of $[ \pm \mathrm{ATR}]$ on the input vowel must be preserved on a correspondent of that vowel in the output.

The response to *\#\# can lead to a number of changes, apart from the desired $\lrcorner \rightarrow$

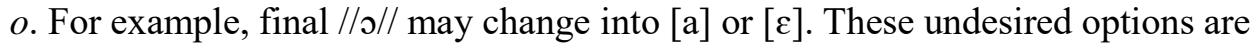
closed by faithfulness constraints, the relevant ones being the following.
a. IDENT[ $[ \pm$ low]:
The value of $[ \pm$ low $]$ on the input vowel must be preserved on a correspondent of that vowel in the output.
b. IDENT[ $[ \pm$ back $]$ :
The value of $[ \pm$ back $]$ on the input vowel must be preserved on a correspondent of that vowel in the output.


This discussion is summarized in (41), where we look at the evaluation of Poló of Marcó Poló.

$(41) / / p o l o / / \rightarrow[p o l o]$

\begin{tabular}{|c|c|c|c|c|}
\hline & *j\# & IDENT $[ \pm$ low $]$ & IDENT $[ \pm$ back $]$ & IDENT $[ \pm \mathrm{ATR}]$ \\
\hline (a) polo & $* !$ & & & \\
\hline (b) polo & & & & $*$ \\
\hline (c) pola & & $* !$ & & \\
\hline (d) pole & & & $* !$ & \\
\hline
\end{tabular}

Candidate (41a) loses because it has lax [0] at the end of the word, a violation of *a\#. Candidates (41c) and (41d) violate the undominated faithfulness constraints and are hence hors de combat. Candidate $(41 \mathrm{~b})$ violates IDENT[ $\pm \mathrm{ATR}]$, but, crucially, this constraint is ranked below the other constraints in (41).

A successful analysis of Final $\rho$-Tensing does not solve the problem of the data in (35), where final $o$ is lax, as in $c \bar{y} t+o$ [0] 'he reads'. Most of these data are related synchronically or diachronically to forms with $[\mathrm{a}]$, as shown by the following comparison. Additionally, in $c \bar{y} t+o[0]$ 'he reads' $-c \bar{y} t+a j+o m[0]$ 'they read', there is an alternation between [0] and [a].

$\begin{array}{llll}\text { Standard Polish } & \text { Kurpian } & \text { Podhale Goralian } & \text { gloss } \\ \text { czyt+a }[\mathrm{a}] & \text { cyt+å }[\mathrm{a}] & \text { cȳt+o }[\mathrm{o}] & \text { 'he reads' } \\ \text { grub+a }[\mathrm{a}] & \text { grub+å }[\mathrm{a}] & \text { hrub+o }[\mathrm{o}] & \text { 'fat' (fem. nom.sg.) } \\ \text { ja }[\mathrm{a}] & \text { jå }[\mathrm{a}] & \text { jo }[\mathrm{o}] & \text { 'I' } \\ \text { dla }[\mathrm{a}] & \text { dlå }[\mathrm{a}] & \text { dlo }[\mathrm{o}] & \text { 'for' }\end{array}$

We have identified the reason for the irregularity in the application of Final $\supset$ Tensing: the [0] from [a] does not undergo the rule. The question is how this descriptive/historical generalization can be incorporated into the phonology of Podhale Goralian. We have no answer to this question at this point.

\section{Conclusion}

The fieldwork carried out in Dzianisz has led to the discovery of new descriptive generalizations. First, the original $o[0]$ and the $o$ from historical $a$ that used to be different are now homophonous. Consequently, the word Polok 'Pole' from the earlier Polåk [a] has two identical open $o$ vowels: [polok]. Second, $y$ [i] as in ryba 'fish' has shifted to tense $e$ : [reba]. Third, Podhale Archaism is still distinct from the rest of Goralian phonology, but the distinction manifests itself in a different way: the 'archaic' $i$ is now a central strongly retracted vowel [i], so $c \bar{y} t a c$ ' read', $s \bar{y} n$ 'son' and zȳtó 'corn' are pronounced [tsitatc], [sin] and [zito], respectively. 
The fourth discovery is that $o / / \mathrm{J} / /$ is tensed to [o] word-finally as in wartkó [vartko] 'quickly'.

In general, the vowel inventory of Podhale Goralian is different from that of Standard Polish in a way that is typical for Polish regional dialects: the system of mid vowels includes //e// and //o// in addition to //ع// and //o//. The neutralization of the two $o$ 's: the original $o$ [0] and the [0] from [a] has disturbed the phonological system because the two $o$ 's behave differently vis-á-vis phonological generalizations. Investigating this behaviour is an agenda for future research.

\section{References}

Avanesov, Ruben Ivanovič. 1968. Russkoye literaturnoye proiznoshenie. Moscow: Prosveshchenie. Biedrzycki, Leszek. 1974. Abriss der polnischen Phonetik. Warszawa: Wiedza Powszechna.

Bilodid, Ivan Konstântinovič. 1969. Suchasna ukrä̈ns'ka literaturna mova. Fonetyka. Kiev: Naukova Dumka.

Chomsky, Noam and Morris Halle. 1968. The Sound Pattern of English. New York: Harper and Row.

Clements, George Nick and Samuel Jay Keyser. 1983. CV Phonology. A Generative Theory of the Syllable. Cambridge, MA: MIT Press.

Decaux, Étienne. 1973. Tzw. archaizm podhalański a sprawa mazurzenia w Małopolsce. Revue des études slaves 49, 119-130.

Dejna, Karol. 1973. Dialekty polskie. Wrocław: Zakład Narodowy im. Ossolińskich.

Halle, Morris. 1992. Phonological features. In William Bright (ed.) International Encyclopedia of Linguistics. Vol. 3. New York \& Oxford: Oxford University Press. 207-212.

Kąś, Józef. 2012. Podstawy ortografii podhalańskiej. In Krzysztof Kudłaciak (ed.), Róźnie tô na tym Bôzým świecie. Bukôwiańskie godki. Bukowina Tatrzańska: Bukowiańskie Centrum Kultury „Dom Ludowy”.

Kąś, Józef. 2015. Ilustrowany leksykon gwary i kultury podhalańskiej. T. 1. Bukowina Tatrzańska: Bukowińskie Centrum Kultury „Dom Ludow'.

Kopernicki, Izydor. 1875. Spostrzeżenia nad właściwościami językowemi w mowie Górali Bieskidowych, $z$ dodatkiem stowniczka wyrazów góralskich. Rozprawy $i$ sprawozdania $z$ posiedzeń Wydziału Filologicznego Akademii Umiejętności III. Kraków: Drukarnia Uniwersytetu Jagiellońskiego pod zarządem Ignacego Stelcla.

Kosiński, Władysław. 1884. Przyczynek do gwary zakopiańskiej. Rozprawy i sprawozdania z posiedzeń Wydziału Filologicznego Akademii Umiejętności X. Kraków: Drukarnia Uniwersytetu Jagiellońskiego pod zarządem Ignacego Stelcla.

Kryński, Adam Antoni. 1884. Gwara zakopiańska. Studyjum dyjalektologiczne. Rozprawy $i$ sprawozdania z posiedzeń Wydziału Filologicznego Akademii Umiejętności X. Kraków: Drukarnia Uniwersytetu Jagiellońskiego pod zarządem Ignacego Stelcla.

Małecki, Mieczysław. 1928. Archaizm podhalański. Monografje polskich cech gwarowych 4. Kraków: Akademia Umiejętności.

McCarthy, John J. and Alan Prince. 1995. Faithfulness and reduplicative identity. In Jill N. Beckman, Laura Walsh Dickey and Suzanne Urbanczyk (eds.), Papers in Optimality Theory. Amherst: GLSA. 249-384.

Nitsch, Kazimierz. 1915. Dialekty języka polskiego. Kraków: Akademia Umiejętności. and 1957. $2^{\text {nd }}$ edition. Wrocław: Zakład Narodowy im. Ossolińskich.

Prince, Alan and Paul Smolensky. 2004. Optimality Theory: Constraint Interaction in Generative Grammar. Oxford: Blackwell. [Revision of 1993 technical report, Rutgers University Center for Cognitive Sciences. Available on Rutgers Optimality Archive, ROA-537.] 
Rozwadowski, Jan Michał. 1915. Historyczna fonetyka, czyli głosownia języka polskiego. Reprinted in Jan Michał Rozwdowski, Wybór pism. Tom I. Pisma polonistyczne. 1959. Warszawa: Państwowe Wydawnictwo Naukowe.

Rubach, Jerzy. 2003. Polish palatalization in Derivational Optimality Theory. Lingua 113, 197-237.

Rubach, Jerzy. 2011. The vocalic system of Kurpian. Studies in Polish Linguistics 6:81-98.

Rubach, Jerzy. 2017. Derivational meanders of high vowel palatalization. Lingua 199:1-26.

Sagey, Elizabeth. 1986. The Representation of Features and Relations in Non-linear Phonology. Doctoral dissertation, MIT.

Schuster-Šewc, Hinc. 1968. Gramatika hornjoserbskeje rěče. Bautzen: Domowina Verlag. Translated into English by Gary H. Toops as Grammar of the Upper Sorbian Language. 1996. München-Newcastle: Lincom Europa.

Stieber, Zdzisław. 1952. Rozwój fonologiczny języka polskiego. Warszawa: Państwowe Wydawnictwo Naukowe.

Stieber, Zdzisław. 1973. A Historical Phonology of the Polish Language. Heidelberg: Carl Winter.

Stopka, Nazimek, Andrzej. 1897. Sabała: portret, życiorys, bajki, powiastki, piosnki, melodye. Kraków: Drukarnia Narodowa.

Stopka, Nazimek, Andrzej. 1911. Rycerze spiacy w Tatrach: fantazye na tle podań ludowych. Kraków: Drukarnia i Zakład Art.-Litogr. Polonia. 